\title{
Inhibitory effects of different medicinal plants on Candida albicans growth")
}

\author{
ZORAN TAMBUR*,**, DESANKA CENIĆ MILOŠEVIĆ*, IVAN MILEUSNIĆ*, \\ RADOJE DODER ${ }^{* *}$, MARJAN MARJANOVIĆ*, BILJANA MILJKOVIĆ SELIMOVIĆ***, \\ ZORAN KULIŠIĆC****, DOLORES OPAČIĆ** \\ *Faculty of Stomatology in Pančevo, 13000 Pancevo, Serbia \\ ** Military Medical Academy, 11000 Belgrade, Serbia \\ ***University of Niš, Medical Faculty, 18000 Nis, Serbia \\ ****University of Belgrade, Faculty of Veterinary Medicine, 11000 Belgrade, Serbia
}

\section{Tambur Z., Cenić Milošević D., Mileusnić I., Doder R., Marjanović M., Miljković Selimović B., Kulišić Z., Opačić D. \\ Inhibitory effects of different medicinal plants on Candida albicans growth}

Summary

The objective of this study was to evaluate the in vitro antifungal properties of ethanol extracts and essential oils of medicinal plants from Serbia against Candida albicans (C. albicans) ATCC 10231.

Ethanol extracts of fifteen plants were investigated, and their effects were compared with those of three different essential oils. The sensitivity of $\mathrm{C}$. albicans to all plants was tested by the agar dilution method. The assay plates were estimated to contain $300,150,75$, and $37.5 \mu \mathrm{g} / \mathrm{ml}$ of active extracts and $100,50,25$, and $12.5 \mu \mathrm{g} / \mathrm{ml}$ of active essential oils. Inocula were applied to agar surfaces, giving approximately $10^{6} \mathrm{cfu} / \mathrm{ml} \mathrm{of} \mathrm{C.} \mathrm{albicans.}$

No inhibitory effects were observed for ethanol extracts of Hypericum perforatum and Salvia officinalis $(\mathrm{MIC}>300 \mu \mathrm{g} / \mathrm{ml})$. The most effective were the ethanol extract of Aesculus hippocastanum (MIC $=37.5 \mu \mathrm{g} / \mathrm{ml}$ ) and the essential oil of Satureja kitaibelii (MIC $=12.5 \mu \mathrm{g} / \mathrm{ml}$ ). Other plants showed MIC from 25 to $300 \mu \mathrm{g} / \mathrm{ml}$.

As far as we know, the inhibitory effects of these medicinal plants against the reference strain of $C$. albicans have not been commonly investigated in our country. Although the essential oil of Satureja kitaibelii shows strong activity against $\mathrm{C}$. albicans, these results need clinical evaluation.

Keywords: medicinal plants, Candida albicans, agar dilution method, antimycotic activity, growth inhibition

Fungi make up approximately 7\% (611 000 species) of eukaryotic species on Earth (16), 600 of which are considered as human pathogens (4). The species Candida albicans (C. albicans), which is responsible for most cutaneous and systemic infections, is endogenous in man, occurring in the buccal cavity, large intestine and vagina (5). This fungus has developed several features and activities that contribute to its pathogenic potential, such as molecules that mediate adhesion to and invasion of host cells, the secretion of hydrolases, the yeast-to-hypha transition, contact sensing and thigmotropism, biofilm formation, phenotypic switching, and a range of fitness attributes (13). C. albicans and, to a lesser extent, other Candida species are present in the oral cavity of up to $75 \%$ of the population. While this colonization generally remains benign in healthy individuals, mildly immunocompromised individuals can frequently suffer from recalcitrant infections

\footnotetext{
1) This study was supported by the Ministry of Education and Science of the Republic of Serbia (Project No 34021).
}

termed oral candidiasis (22). Due to the antimicrobial properties of plant secondary metabolites (tannins, terpenoids, alkaloids, quinones and flavonoids), their usage have made large contributions to human health and well-being (17). Approximately $60-80 \%$ of the world's population still relies on traditional medicine for treatment of common illnesses (24). Numerous healthful properties of medicinal plants have been known in Serbia since ancient times, and plant materials have been used in traditional treatment because of their medicinal effects.

\section{Material and methods}

Collection of plant material. The following medicinal plants were collected in northern Serbia: the free-growing plants Aesculus hippocastanum, Artemisia absinthium, Capsella bursa-pastoris, Hypericum perforatum, and Thymus vulgaris, and the cultivated plants Achillea millefolium, Calendula officinalis, Malva mauritanica, Origanum majorana, Plantago lanceolata, Sinapis alba, Tilia cordata, and 
Teucrium montanum. Acorus calamus and Salvia officinalis are both free-growing and cultivated medicinal plants.

Preparation of ethanolic extracts. Dry plants $(150 \mathrm{~g})$ were milled into fine powder with an electric blender. Extraction was done in a percolator, using $500 \mathrm{ml}$ of $(70 \%)$ ethanol, with low-pressure evaporation following extraction. The content of the extract was left for at least $16 \mathrm{~h}$. The amount of the extract was six times the volume of the starting drug ( $1: 6$ extract). The extract was stored and finally passed through a $0.22 \mu \mathrm{m}$ filter (Millipore, Billerica, MA). After dry substance had been obtained in an evaporator, the extracts were kept at $4^{\circ} \mathrm{C}$ until use (8).

Extraction of essential oils. The essential oils of freegrowing Rosmarinus officinalis (cultivated as well), Satureja kitaibelii and Salvia officinalis were obtained by distillation in a Clevenger-type apparatus.

Antimicrobial activity. Microbial strain. The ethanol extracts and essential oils were individually tested against C. albicans ATCC strain 10231. The yeast was cultured overnight at $37^{\circ} \mathrm{C}$ in Mueller-Hinton Broth at $\mathrm{pH}=7.4$.

Determination of the minimum inhibitory concentration (MIC). The antimycotic activity of plant extracts and essential oils was investigated by the agar dilution method. The assay was carried out with the yeast species $C$. albicans ATCC strain 10231. Serial dilutions of plant extracts and essential oils were prepared in plates, and the assay plates were estimated to contain $300,150,75$, and 37.5 $\mu \mathrm{g} / \mathrm{ml}$ of active extracts and $100,50,25$, and $12.5 \mu \mathrm{g} / \mathrm{ml}$ of active essential oils. Inocula were applied to Sabouraud dextrose agar surfaces, giving approximately $10^{6} \mu \mathrm{g} / \mathrm{ml}$ of C. albicans. All plates were incubated for about 48 to $72 \mathrm{~h}$ under anaerobic conditions. MIC was taken as the lowest concentration of an extract/essential oil that produced no visible fungal growth as compared to the control growth. The extracts and oils were tested in triplicates.

\section{Results and discussion}

The plant extracts and essential oils obtained from free growing and/or cultivated medicinal plants were investigated for inhibitory effects on C. albicans growth. The inhibitory effects were expressed by MIC. Hypericum perforatum and Salvia officinalis extracts $(\mathrm{MIC}>300 \mu \mathrm{g} / \mathrm{ml})$ did not inhibit the growth of C. albicans (Tab. 1). The ethanol extracts of Achillea millefolium, Acorus calamus, Artemisia absinthium, Calendula officinalis, Capsella bursa-pastoris, Malva mauritanica, Origanum majorana, Plantago lanceolata, Sinapis alba, Tilia cordata and Teucrium montanum showed MIC at $300 \mu \mathrm{g} / \mathrm{ml}$. Thymus vulgaris extract showed MIC at $150 \mu \mathrm{g} / \mathrm{ml}$, while Aesculus hippocastanum extract had the highest antimycotic activity, with $\mathrm{MIC}=37.5 \mu \mathrm{g} / \mathrm{ml}$. The essential oils of Rosmarinus officinalis, Salvia officinalis and Satureja kitaibelii showed MIC at $50 \mu \mathrm{g} / \mathrm{ml}, 25 \mu \mathrm{g} / \mathrm{ml}$, and 12.5 $\mu \mathrm{g} / \mathrm{ml}$, respectively (Fig. 1).

At $\mathrm{MIC}>300 \mu \mathrm{g} / \mathrm{ml}$, Hypericum perforatum and Salvia officinalis extracts had no inhibitory effects against $C$. albicans in this investigation, while extracts of $H$. perforatum grown under controlled conditions
Tab. 1. MIC values of ethanolic extracts against Candida albicans ATCC strain 10231

\begin{tabular}{|l|c|}
\hline \multicolumn{1}{|c|}{ Plants } & MIC $\left(\mu \mathrm{g} \mathrm{ml} \mathrm{l}^{-1}\right)$ \\
\hline Hypericum perforatum & 300 \\
\hline Salvia officinalis & 300 \\
\hline Achillea millefolium & 300 \\
\hline Acorus calamus & 300 \\
\hline Artemisia absinthium & 300 \\
\hline Calendula officinalis & 300 \\
\hline Capsella bursa-pastoris & 300 \\
\hline Malva mauritanica & 300 \\
\hline Plantago lanceolata & 300 \\
\hline Sinapis alba & 300 \\
\hline Teucrium montanum & 300 \\
\hline Tilia cordata & 300 \\
\hline Origanum majorana & 300 \\
\hline Thymus vulgaris & 150 \\
\hline Aesculus hippocastanum & 37.5 \\
\hline
\end{tabular}

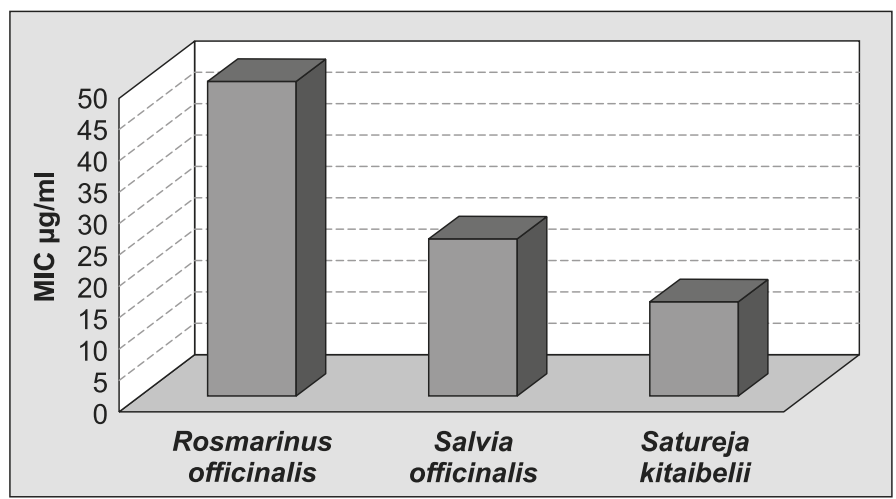

Fig. 1. MIC values of essential oils of Rosmarinus officinalis, Salvia officinalis and Satureja kitaibelii against $C$. albicans ATCC strain 1023

showed greater antifungal activity than did wild plants (27). Similar to the results of this study, Cardoso et al. (7) verified that Salvia officinalis tincture, at the concentrations tested, did not exhibit activity against C. albicans and C. tropicalis.

In the present work, eleven plant extracts showed weak antimycotic activity, with MIC of $300 \mu \mathrm{g} / \mathrm{ml}$. Many authors reported that plant extracts showed higher efficacy against bacteria than against fungi. In a study by Stanković et al. (26), C. albicans strains were inhibited only by extracts of Teucrium scordium and T. botrys. In general, plant extracts exhibited higher antibacterial activity than antifungal activity, which was also confirmed for extracts of Tilia rubra subsp. caucasica (18).

Candan et al. (6) reported that the oil of Achillea millefolium, which possessed stronger antimicrobial activity than the extracts tested, exhibited moderate activity against $C$. albicans and weak activity against Candida krusei. The essential oil of Sinapis alba had a broad-spectrum antimicrobial activity 
(19). In another study, the antibacterial activity of mixed ethanol extracts (Tribulus terrestris, Capsella bursa-pastoris, Glycyrrhiza glabra) provided scientific support for their usage in the treatment of oral infections caused by Streptococcus mutans, Streptococcus sanguis, Actinomyces viscosus, Enterococcus faecalis, Staphylococcus aureus, and Escherichia coli (25). Although methanol and ethanol extracts of Calendula officinalis petals exhibited excellent antifungal activity (9), it is noteworthy that Alemu and Andualem (1) found the inhibition zone of the water extract of Plantago lanceolata against clinical $C$. albicans to be statistically greater than that of acetone and methanol extracts.

In contrast to the results obtained in this work, the methanol extract of Origanum majorana, because of its strong microbicidal properties and superiority over commercial microbicides, expressed high activity (12) against seven fungi (Fusarium solani, C. albicans, Aspergillus niger, A. parasiticus, Rhizopus oryzae, Rhizoctonia oryzae-sativae, Alternaria brassicicola) and six bacteria (Bacillus subtilis, B. megaterium, Escherichia coli, Proteus vulgaris, Pseudomonas aeruginosa, Staphylococcus aureus). In addition, significant anti-yeast activity of Acoruscalamus extracts against $C$. albicans and antifungal activity of Malva sylvestris tincture against all tested strains at lower concentrations were reported by several authors $(2,7)$.

The results of antimicrobial activity against seven common food-related bacteria and the fungus $C$. albicans ATCC 10231, evaluated by the disk diffusion method, demonstrated that the essential oil of Thymus vulgaris possesses strong antimicrobial properties and might become a new source of natural antiseptics with applications in the pharmaceutical and food industry (3). In the present study, the extract of Thymus vulgaris at $\mathrm{MIC}=150 \mu \mathrm{g} / \mathrm{ml}$ showed moderate antifungal activity.

Among all extracts investigated in this work, Aesculus hippocastanum extract exhibited the strongest activity (MIC $=37.5 \mu \mathrm{g} / \mathrm{ml}$ ) against $C$. albicans. The compounds isolated and identified from the Aesculus species possess diverse activities, including antiinflammatory, antitumor, antiviral, antioxidative, and antigenotoxic properties. More than 210 compounds isolated and identified from the genus Aesculus include triterpenoids, triterpenoid glycosides (saponins), flavonoids, coumarins, carotenoids, long fatty chain compounds, and some other classes of compounds (29). The highest antibacterial activity of methanolic extracts of Aesculus hippocastanum was determined by the disc diffusion method against Pseudomonas aeruginosa, and strong antimicrobial activity was found against Listeria ivanovii (28). A study by Roy et al. $(20,21)$ demonstrated that extracts of Aesculus hippocastanum at different concentrations showed varying degrees of antibacterial and antimycotic activities against microorganisms playing a major role in dental caries and periodontal disease. The highest ethanolic concentrations were the most effective against Streptococcus mutans, Streptococcus sanguis, C. albicans, and Penicillium morneffi, while their efficacy against Streptococcus mitis and Mucor spp. was the lowest.

With regard to antifungal activity, it was the weakest for the essential oil of Rosmarinus officinalis in the present study $(\mathrm{MIC}=50 \mu \mathrm{g} / \mathrm{ml})$. Antifungal activity of this essential oil has also been reported by Santoyo et al. (23). Although the extract of Rosmarinus officinalis obtained in the first 60 minutes did not show sufficient antifungal activity to inhibit the growth of C. albicans, that activity was improved with increasing extraction time (10). In this study, the essential oil of Salvia officinalis showed moderate activity against C. albicans ( $\mathrm{MIC}=25 \mu \mathrm{g} / \mathrm{ml})$, which is in contrast to results obtained by Miladinović and Miladinović (14). According to the results of this study, the highest activity against $C$. albicans was shown by the essential oil of Satureja kitaibelii $(\mathrm{MIC}=12.5 \mu \mathrm{g} / \mathrm{ml})$, which had stronger antibacterial and antifungal activity than did ethanol extracts (15). Other authors report the growth inhibition of $C$. albicans yeast by the essential oil of Artemisia absinthium (11).

The present investigations of the antifungal activity of different medicinal plants against $C$. albicans revealed that the extract of Aesculus hippocastanum and the essential oil of Satureja kitaibelii were the most effective. Their usage in the control of oral diseases and prevention of systemic diseases for which this organism is responsible needs further studies.

\section{References}

1. Alemu F., Andualem B.: Antimicrobial potentials of different solvent extracts of Justicia landonoides and Plantago lanceolata against standard and drug resistant human bacterial pathogens. Int. J. Microbiol. Res. 2014, 5, 6-18.

2. Asha Devi S., Ganjewala D.: Antimicrobial activity of Acorus calamus (L.) rhizome and leaf extract. Acta Biol. Szeged 2009, 53, 45-49.

3. Borugă O., Jianu C., Mişcă C., Goleţ I., Gruia A. T., Horhat F. G.: Thymus vulgaris essential oil: chemical composition and antimicrobial activity. J. Med. Life 2014, 7, 56-60.

4. Brown G. D., Denning D. W., Levitz S. M.: Tackling human fungal infections. Science 2012, 336, 647.

5. Calderone R. A., Clancy C. J. (ed): Candida and Candidiasis. ASM Press, Washington DC 2012.

6. Candan F., Unlu M., Tepe B., Daferera D., Polissiou M., Sökmen A., Akpulath $H$. A.: Antioxidant and antimicrobial activity of the essential oil and methanolextracts of Achillea millefolium subsp. millefolium Afan. (Asteraceae). J. Ethnopharmacol. 2003, 87, 215-220.

7. Cardoso A. M. R., Cavalcanti Y. W., de Fátima Dantas de Almeida L., de Lima Pérez A. L. A., Padilha W. W. N.: Antifungal activity of plant-based tinctures on Candida. RSBO 2012, 9, 25-30.

8. Cenić Milošević D., Tambur Z., Bokonjić D., Ivančajić S., Stanojković T., Grozdanić N., Juranić Z.: Antiproliferative effects of some medicinal plants on HeLa cells. Arch. Biol. Sci. 2013, 65, 65-70.

9. Efstratiou E., Hussain A. I., Nigam P. S., Moore J. E., Ayub M. A., Rao J. R. Antimicrobial activity of Calendula officinalis petal extracts against fungi, as well as Gram-negative and Gram-positive clinical pathogens. Complement Ther. Clin. Pract. 2012, 18, 173-176.

10. Genena A. K., Hense H., Smânia Junior A., de Souza S. M.: Rosemary (Rosmarinus officinalis) - a study of the composition, antioxidant and antimicrobial activities of extracts obtained with supercritical carbon dioxide. Tecnol. Aliment. Campinas 2008, 28, 463-469.

11. Juteau F., Jerkovic I., Masotti V., Milos M., Mastelic J., Bessiere J. M., Viano J.: Composition and antimicrobial activity of the essential oil of Artemisia absinthium from Croatia and France. Planta Med. 2003, 69, 158-161. 
12. Leeja L., Thoppil J. E.: Antimicrobial activity of methanol extract of Origanum majorana L. (Sweet marjoram). J. Environ. Biol. 2007, 28, 145-146.

13. Mayer F. L., Wilson D., Hube B.: Candida albicans pathogenicity mechanisms. Virulence 2013, 4, 119-128.

14. Miladinović D., Miladinović Lj.: Antimicrobial activity of essential oil of sage from Serbia. Facta Universitatis 2000, 2, 97-100.

15. Milosavljević P. N., Miladinović Lj.: Antibacterial activity and chemical composition of essential oil of Savory (Sature jakitaibelii Wierzb. ex Heuff). Proc. $6^{\text {th }}$ Symp. on Flora of the Southeastern Serbia, Sokobanja 2000, p. 81-85.

16. Mora C., Tittensor D. P., Adl S., Simpson A. G. B., Worm B.: How many species are there on Earth and in the ocean? PLoS Biol. 2011, e1001127.

17. Lewis K., Ausubel F. M.: Prospects for plant-derived antibacterials. Nat. Biotechnol. 2006, 12, 1504-1507.

18. Özbucak B. T., Akçin E. Ö., Ertürk Ö.: The change in ecological, anatomical and antimicrobiological properties of the medicinal plant Tilia rubra dc. subsp. caucasica (rupr.) v. engler along an elevational gradient. Pak. J. Bot. 2013, 45 , 1735-1742.

19. Peng C., Zhao S. Q., Zhang J., Huang G. Y., Chen L. Y., Zhao F. Y.: Chemical composition, antimicrobial property and microencapsulation of Mustard (Sinapis alba) seed essential oil by complex coacervation. Food Chem. 2014, 165C, 560-568.

20.Roy A., Geetha R. V., Lakshmi T.: Evaluation of the antimycotic activity of aqueous and ethanolic extracts of Aesculus hippocastanum - an In vitro study. Int. J. Drug Dev. Res. 2011, 3, 335-338.

21. Roy A., Geetha R. V., Lakshmi T.: In vitro evaluation of antibacterial activity of aqueous and ethanolic extracts of Aesculus hippocastanum on oral microbes. Asian J. Pharm. Clin. Res. 2011, 4, 90-92.
22. Ruhnke M.: Candida and Candidiasis: Skin and mucous membrane infections. ASM Press, Washington DC 2002

23. Santoyo S., Cavero S., Jaime L., Ibañez E., Señoráns F. J., Reglero G.: Chemica composition and antimicrobial activity of Rosmarinus officinalis L. essential oil obtained via supercritical fluid extraction. J. Food Prot. 2005, 68, 790-795.

24. Schuster D., Wolberg G.: Identification of bioactive natural products by pharmacophore-based virtual screening. Curr. Pharm. Des. 2010, 16, 1666-1681 .

25. Soleimanpour S., Sadat Sedighinia F., Safipour Afshar A., ZarifR., Ghazvini K. Antibacterial activity of Tribulus terrestris and its synergistic effect with Capsella bursa-pastoris and Glycyrrhiza glabra against oral pathogens: an in-vitro study. Avicenna J. Phytomed. 2015, 5, 210-217.

26. Stanković M. S., Stefanović O., Čomić Lj., Topuzović M., Radojević I. Solujić S.: Antimicrobial activity, total phenolic content and flavonoid concentrations of Teucrium species. Cent. Eur. J. Biol. 2012, 7, 664-671.

27. Tocci N., Simonetti G., D'Auria F. D., Panella S., Palamara A. T., Ferrari F., Pasqua G.: Chemical composition and antifungal activity of Hypericum perforatum subsp. angustifolium roots from wild plants and plants grown under controlled conditions. Plant Biosystems 2013, 147, 557-562.

28. Vatlák A., Kolesárová A., Vukovič N., Rovná K., Petrová J., Brindza J., Nōžková J.: Antimicrobial activity of medicinal plants against different strains of bacteria. J. Microbiol. Biotech. Food Sci. 2014, 3, 174-176.

29. Zhang Z., Shiyou L. S., Lian X. Y.: An overview of genus Aesculus L. Ethnobotany, phytochemistry, and pharmacological activities. Pharm. Crops. 2010, 1, 24-51.

Corresponding author: Prof. dr Zoran Tambur, Faculty of Stomatology in Pančevo, Žarka Zrenjanina 179, 13000 Pancevo, Serbia; e-mail: tambur zoran@gmail.com 